\title{
THE SETTING AND THE PARTICIPANTS
}

In March 1947, the Atomic Energy Commission moved its headquarters to a building located at Nineteenth Street and Constitution Avenue N.W., which had been used during World War II by the Joint Chiefs of Staff. But the AEC retained space in Building T-3, a "temporary" structure, located three blocks away, at Sixteenth and Constitution, not far from the Washington Monument, and that is where the Personnel Security Board held its month-long hearing in the case of J. Robert Oppenheimer.

Room 2022, in which the testimony was taken, was rectangular-shaped. It was "a sort of long dark room," participants recalled, "all very bare." Three tables in the center were arranged in the form of a "T," with the head table parallel to the right side of the room as one entered it. The members of the board were seated at that table: Gordon Gray in the middle, flanked by Ward V. Evans to his left and Thomas A. Morgan to his right. The recorder, Albert J. Gasdor, was positioned in front of them. Two long, narrow tables, perpendicular to the head table, were reserved for the attorneys. To the board members' right, their backs to the windows, were the AEC's lawyers: Roger Robb and Carl Arthur Rolander Jr., and a classification officer. Opposite them, facing the windows, were Oppenheimer's attorneys: Lloyd K. Garrison, Herbert S. Marks, Samuel J. Silverman, and Allan B. Ecker. Witnesses were seated when they testified in a chair, located at the base of the "T," facing the members of the board.

Behind the chair was a leather sofa on which Oppenheimer sat when he was not testifying. Witnesses therefore would see him as they entered the room, but would have their backs to him as they testified.

In selecting the Personnel Security Board, Lewis L. Strauss, the Atomic Energy Commission chairman, and William Mitchell, the general counsel, had 
certain considerations in mind. For obvious reasons, they wanted one of the members to be a lawyer and another to be a scientist. They sought individuals whose stature was such that their decision would carry weight. They preferred that one and possibly two of the board members be Democrats to avoid the risk that a ruling might appear to be politically motivated. In fact, however, they wanted individuals who were likely to rule against Oppenheimer, although there was no way to guarantee that outcome. According to an FBI memorandum, Strauss told Mitchell that "if this case is lost the atomic energy program and all research and development connected thereto will fall into the hands of 'left-wingers.' . . . [I]f Oppenheimer is cleared, then 'anyone' can be cleared regardless of the information against them."

Gordon Gray, forty-five years of age, president of the University of North Carolina since 1950, had exactly the right credentials, Strauss and Mitchell believed, to serve as the board chairman. Born to a wealthy Winston Salem, North Carolina, family-his father was head of R. J. Reynolds Tobacco Company-Gray went to a private preparatory school in Virginia, attended the University of North Carolina, and then entered Yale Law School, receiving his degree in 1933. Elected a state senator in 1939 and 1941, he enlisted in the army as a private during World War II, rose to the rank of captain, later served as Assistant Secretary of the Army, and wound up, in 1949, as President Harry S. Truman's Secretary of the Army. He was a Democrat, although a conservative one who had refused to support Adlai Stevenson in 1952 because he considered the nominee soft on communism.

Joining Gray on the board was Thomas A. Morgan, who had recently retired as president and chairman of the board of the Sperry Corporation. Like Gray, he hailed from North Carolina, but the two men's backgrounds could not have been more dissimilar. The son of an impoverished tobacco farmer, Morgan had to walk three miles every day to get to public school, earned money while attending high school by working as a carpenter and traveling salesman, and in 1908, at the age of nineteen, enlisted in the navy. While serving as an apprentice electrician on a battleship, he met Elmer Sperry, the inventor of the gyrocompass, and made such a favorable impression that when he was discharged from the service in 1912 Sperry invited him to join his company. By the late 1920s Morgan had become its president. He retired in 1952, but continued, among other things, to chair the United Negro College Fund drive in New York City. He was described as "a baldish man with gray eyes who bore a rose tattoo on his left arm."

Both Gray and Morgan were Democrats, but the third member of the board, Dr. Ward V. Evans, was a rock-ribbed conservative Republican who was quoted as saying, "The closest I ever came to being a Communist was voting for Franklin Roosevelt in 1932." Born in Pennsylvania in 1883, he attended Franklin and Marshall College, taught for a few years at a private school near Poughkeepsie, New York, and eventually decided to study for a doctorate in chemistry, which he received from Columbia University in 1916. He served in the army during World War I, and afterward he taught chemistry and served 
as department chairman at Northwestern University. After his retirement, he moved to Loyola University of Chicago, where he taught from 1947 to 1951. He had previously served on AEC hearing boards in Chicago.

In security clearance hearings, typically, the Atomic Energy Commission utilized its own lawyers who tried to present all the evidence, pro and con, to the members of the board. But the highly unusual circumstances of the Oppenheimer hearing led the agency to depart from this practice. Reaching outside the counsel's office, Strauss selected an attorney who would, in truth, act as a prosecutor. Roger Robb's name was suggested to Strauss by Deputy Attorney General William P. Rogers. The forty-seven-year-old Robb was a Yale graduate who had gone on to receive a law degree at Yale in 1931, and then spent seven years as an Assistant United States Attorney in Washington, D.C. Since 1938 he had engaged in private practice, handling a number of high-profile cases and earning a reputation as a skilled, combative trial lawyer.

Assisting Robb in preparing the case, although he did not question any of the witnesses, was Carl Arthur Rolander Jr. Born in Kansas in 1920, Rolander did not attend college; instead, at the age of twenty, he went to work for the Federal Bureau of Investigation. He remained with the FBI until 1944, when he entered the army, and in 1947 he joined the staff of the Atomic Energy Commission. Meanwhile, he attended Catholic University, working toward a law degree, which he received in 1949. Given his background, it was only logical for him to become the AEC's deputy director of security, and at the hearing he would sometimes decide whether or not certain documents could be declassified.

One of the reasons why Strauss turned to Roger Robb was his fear that the AEC's own staff lacked the courtroom experience to deal with the highpowered legal team Oppenheimer was assembling. To handle his defense, the physicist selected Lloyd K. Garrison, whom he had met in April 1953, when Garrison became a member of the board of trustees of the Institute for Advanced Study. A great-grandson of the abolitionist William Lloyd Garrison, and scion of a wealthy New York City family known for its contributions to literature as well as the law, Garrison, born in 1897, served in the navy during World War I, attended Harvard College, class of 1919, and went on to Harvard Law School, receiving his degree in 1922. He signed on with a prominent Wall Street law firm, but left after a few years to branch out on his own. In 1932 he became dean of the University of Wisconsin Law School, where he remained until 1945, taking leaves as necessary to serve the federal government in the area of labor-management relations: he was chairman of the National Labor Relations Board in 1934, and later general counsel, executive director, and eventually chairman of the National War Labor Board from 1942 to 1945. When the war was over, he became a partner in the New York City firm of Paul, Weiss, Rifkind, Wharton \& Garrison, but he still found time for social causes, serving, for example, as president and director of the National Urban League.

Oppenheimer's friend and trusted adviser, Herbert S. Marks, also partici- 
pated in his defense. Marks at first resisted any formal involvement because of his prior association with the Atomic Energy Commission, but as the hearing progressed he assumed an ever larger role. Forty-seven years of age, Marks was a graduate of the University of Pennsylvania and Harvard Law School, class of 1932. Like many other Harvard Law graduates of his generation, he went to Washington to participate in the New Deal. He served as attorney and also general counsel for the Tennessee Valley Authority from 1934 to 1939, and the Bonneville Power Administration from 1939 to 1940. When the United States entered World War II, Marks became counsel to the War Production Board from 1941 to 1945. In 1946 he advised Under Secretary of State Dean Acheson on problems relating to atomic energy, and in 1947 he served as the AEC's general counsel. Since then he had been a partner in Marks and Trowbridge.

Two members of Garrison's law firm also aided in the defense. Samuel J. Silverman, whose parents had emigrated to the United States from Russia in 1913 when he was five years old, was a graduate of Columbia Law School. Like both Garrison and Marks, he served in various federal agencies, working as an attorney for the United States Railroad Retirement Board in 1936 and 1937, and for the Foreign Economic Administration in 1944. After the war he joined Paul, Weiss, Rifkind, Wharton \& Gärrison, where he acquired extensive trial experience. The final member of the defense team, Allan B. Ecker, a recent graduate of Harvard Law School, was present throughout the hearing, although he did not examine any of the witnesses.

The members of the Personnel Security Board, the attorneys representing the Atomic Energy Commission, and those defending Oppenheimer were, for the most part, accustomed to spending their working days in comfortable, well-appointed offices or boardrooms. But for four weeks in the spring of 1954 they appeared, each morning, in a small room in a shabby two-story building in downtown Washington, D.C., where J. Robert Oppenheimer's fate was to be decided. 